\title{
The Level of Implementation of the Strategic Management in Primary Schools ${ }^{\mathrm{i}}$
}

\author{
Şenyurt Yenipınar ${ }^{1, *}$, Nuri Akgün ${ }^{2}$ \\ ${ }^{1}$ Faculty of Education, Aksaray University, 68100 Aksaray, Turkey \\ ${ }^{2}$ Faculty of Education, Abant Izzet Baysal University, Bolu, Turkey
}

Copyright $\mathrm{O} 2017$ by authors, all rights reserved. Authors agree that this article remains permanently open access under the terms of the Creative Commons Attribution License 4.0 International License

\begin{abstract}
In this study, primary school principals and teachers apply - determination of the degree to which the views of the primary institutions. The research was carried out in the scan; working population in Istanbul province, Turkey on the Asian side in the Ataşehir, Kadıköy, Kartal, Maltepe and the townships of Sultanbeyli the academic year 2011-2012, who served 192 primary school principal, and 400 teachers. Primary school principal and teachers for the purposes of determining views are applied to the "Strategic level of Management Schools Measuring Scale" data collection tool was used. Statistical methods of evaluating identifier data (number, percentage, mean, standard deviation). Quantitative data to compare the difference between the two groups of T-Test, is the number of $n$ low Man Whitney U Test was used. In the case of more than two group comparisons between the groups of One-Way Anova Test and the diversity of the group, the number of cases where the Scheffe, Wallis Test has been used low Kruskal. Based on the findings of the research, the following conclusions: All subjects participating in the study, according to the average of: strategic management in primary schools; "strategic thinking", "creating a strategic analysis, routing, and strategy", "a high level of strategic application and evaluation".
\end{abstract}

Keywords Management, Strategy, Strategic

Management

\section{Introduction}

To provide individuals' needs and demands which require more strength and talent than an individual has there have emerged a need for organizational life, organization and management. Organized living makes people's life easier and it helps them to be stronger and superior than other individuals or groups. Societies that can be organized well and find effective management models for these organizations and apply these models have always been superior to those that cannot achieve this. They have always dominated (Genç [12]). Throughout history, organizational and managerial concepts which are in search of development and settlement gained importance with the help of industrial revolution, so ideal organization and management techniques have been the target as the part of changing conditions. However, a true and constant model couldn't be found due to the fact that searching brings changing and vice versa. And development brings about uncertainty (Çetinkanat [6]; Erdem [8]; Ertan [11]).

In his book "The Prince" Machiavelli states that an intelligent leader must be prepared not only for the age's conflicts but also the future problems. He should mind the future and fight with the problems by using his overall abilities. Viewing the future and taking action beforehand is a gift given to the wise men (Machiavelli, Translated: Türk [17]). To survive in a constantly changing world, organizations should be multi-dimensional and international. Besides, they should make projects regarding the qualified and competitive environment and be always in search. Organizations that can achieve this level of awareness have always tried to shape the future and reach the strategic management understanding in practice (MEB [18]). The reason is that strategic management helps shaping and having future instead of expecting it (Güçlü [13]). In today's World, changing is so fast. In such an environment, one of the things that organizations need most is strategy and strategic methods. Both an internal way which increases operational effectiveness and an external view which compensate the whole organization. It is only possible to constitute 20th century's institutions with the help of such an organizational culture (Kırım [15]). Today and tomorrow, the way to success and maintain it is to compete for learning. Those who learn and implement faster are always one move ahead compared to their rivals. The only way to achieve this is strategic thinking and behaviour. In today's world in which changing is spontaneous and time-space distinction is over, strategic management has become a fast-growing area of investigation (Koç and Taşçı [16]).

Aktan [2] defines the word "strategy" as the art of 
providing agreement and coordination to realize a common purpose. Strategy in management is a plan or a model which units the main purposes, policies and activities of a group. A well-organized strategy takes the organization to the goal and enables it to allocate its resources based on one and only applicable unity according to the internal talents and weaknesses, any possible changes in the environment and rivals (Quinn, Henry and Robert [19]).

Educational systems must be in struggle for realizing an education which is suitable for universal values for they are the systems established to bring up individuals for future societies (Çelik [5]). For community's benefits, they should always develop and be ready for any threats in the future. To accomplish this, managerial understanding, organizational structures and leadership approaches should be revaluated according to necessities of the time. School principals, as others do, have to administer regarding the current conditions to keep their organization alive and enable societies to fulfil their duties (Drucker [7]).

Changing and development in Turkey is closely related to European Union (Terzi [20]). Each and every state or private organization in Turkey is directly or indirectly affected by any economic or social policies of European Union. Thus, there has emerged a necessity for a comprehensive reconstruction of Turkish Public Administration. In this framework, a strategic management approach which is sensitive to society's reactions, participant, clear with purposes and priorities, transparent, accountable and effective has been adopted (MEB [18]). Strategic plans that are prepared regarding development plans, yearly programs and other related programs come into force after going through the processes secretariat of the state planning organisation and other relevant institutions (MEB [18]). For this purpose, "Regulations regarding strategic planning procedures and principles" was made in accordance with the 9th articles of law 5018 by secretariat of the state planning organisation. According to this regulations strategic management studies started to be conducted in a staged calendar. According to this calendar, Ministry of Education went into a strategic management which took the years 2014-2015 in. Strategic plans were finished at the end of 2010 after studies were started in particular central organizational District National Directorate for National Education and Province Directorate for National Education. However, process is the important part of implementing strategic management effectively. Strategic document is nothing on its own. It is very significant for all managers and stuff to share the same values and understanding and they must work together (Bush and Coleman [3]). For the success of strategic management, all staff should believe the applicability of the procedures and support it (Erdogan [10]). Just in this case, a rapid and economic management process can be provided.

\subsection{Purpose of the Study}

The purpose of this study: to establish primary school principals' and teachers' views on the level of implementation of strategic management in primary schools. This study is considered vital in that evaluating conditions, eliminating deficiencies and developing new qualifications in relation to strategic management in primary schools.

\subsection{Problem}

What are the views of school principals and teachers on the level of implementation of strategic management?

\subsection{Sub Problems}

1.3.1. Is there a remarkable difference between principle and teacher views on strategic management in primary schools?

1.3.2. Is there a remarkable difference between principles' and teachers' views on strategic management in primary schools depending on variables such as gender, age, graduate school, field or professional seniority?

\section{Methodology}

This is a quantitative research in which a descriptive model was used (Arlı and Nazik [3]; Karasar [14]; Yıldırım [23]).

\subsection{Population}

Population of the study is composed of primary school principals and teachers who lived in provinces such as Ataşehir, Kadıköy, Kartal, Maltepe and Sultanbeyli which are located in Asian Side of İstanbul and who were on duty between the years 2011-2012. Data which is included in the population was obtained from İstanbul Province Directorate for National Education Strategy Development unit. All of the principles of the 208 primary schools which are in the population of the study were given a scale form. However, school principles' population is 192 because of the fact that 192 of the forms could be evaluated.

\subsection{Sample}

Due to the fact that it is impossible to reach all of the students, sampling was preferred. 7781 teachers work in 208 schools which are in the population of the research. These teachers were listed separately according to their provinces. Considering every school as a cluster, the scale forms were given to the teachers by choosing two of them randomly and objectively from each school by using sampling. Sample represents population.

\subsection{Data Collection}

With the purpose of collecting data, "The Level of 
Implementation of Strategic Management Measurement Scale" which was developed by Yenipınar [22] was used in this research. Reliability of the scale was found 0,988 . After factor analysis, 3 factors with \% 69.02 variance emerged. Reliability of 30 items which constitute "strategic thinking" factor was found $\alpha=0,984$. After factor analysis, $\% 32,4$ variance was attained. Reliability of the 14 items which constitute "Strategic analysis, guidance and forming strategy" factor was found $\alpha=0,960$. After factor analysis, $\% 21,1$ variance ration was attained. Reliability of 9 items which constitute "Strategic implementation and evaluation" was found $\alpha=0,95$. After factor analysis, $\% 15,5$ variance ratio was attained. For this scale, test-retest method was applied on 200 people. Test-retest correlation was high $(\mathrm{r}=0,889)$. Reliability level of the scales varies between $\% 94$ and \% 99 . It is seen that internal consistency of scales and hypothesis which belong to sub-categories and they are highly reliable.

\subsection{Data Analysis}

Data which was obtained from the research was analysed by using Statistical Package for Social Sciences program. To the solution of the first sub-problem: descriptive statistics methods (percentage, average, standard deviation); T-test for the difference between two groups for comparing quantitative data; Man Whitney $\mathrm{U}$ test in case $\mathrm{n}$ is low in groups; One Way Anova test for more than two groups and Scheffe test to find out the group which makes the difference. To the solution of second sub-problem: For the difference between two groups T-test and in case $\mathrm{N}$ number is low Man Whitney U Test was used. In case of more than two groups, One Way Anova Test and to find out the group which makes the difference Scheffe Test, in case of N number is low in groups Kruskal Whallis Test was used. "Level of Implementation of Strategic Management in Schools Measurement Scale" which was used to collect data was applied for all principals and teachers, however not all of the surveys were returned. The information related to the surveys which were carried out and evaluated is as following in Table 1.

As it can be seen in Table 1, 192 (\% 92.30) school principals out of 208, expressed their opinions. Because of the fact that all of the answered scales were suitable for evaluation, 192 (\% 92.30) principles scales were evaluated and statistical process was done. 400 teachers $(\% 96.15)$ out of 416 teachers who constitute population made their statements by answering the scale. After analysing the scales, it was seen that all of them can be assessed and statistical process was done. In the research, principles and teacher were given 624 scales. 593 (\% 94, 22) of them were answered and statistical process was done on them.

Table 1. The information Related to the Surveys Which Were Carried Out and Evaluated

\begin{tabular}{|c|c|c|c|c|c|c|c|}
\hline & Distributed & \multicolumn{2}{|c|}{ Answered } & \multicolumn{2}{|c|}{ Out of assessment } & \multicolumn{2}{c|}{ Evaluated } \\
\cline { 2 - 8 } & $\mathrm{n}$ & $\mathrm{n}$ & $\%$ & $\mathrm{n}$ & $\%$ & $\mathrm{n}$ & $\%$ \\
\hline Principal & 208 & 192 & 92,30 & - & - & 192 & 92,30 \\
\hline Teacher & 416 & 400 & 96,15 & - & - & 400 & 96,15 \\
\hline Total & 624 & 592 & 94,22 & 0 & 0 & 592 & 94,22 \\
\hline
\end{tabular}

Table 2. Demographic Aspects of Primary School Principals and Teachers

\begin{tabular}{|c|c|c|c|c|c|}
\hline & & \multicolumn{2}{|c|}{ Principle } & \multicolumn{2}{|c|}{ Teacher } \\
\hline & & $\mathrm{n}$ & $\%$ & $\mathrm{n}$ & $\%$ \\
\hline \multirow{2}{*}{ Gender } & Female & 31 & 16,1 & 184 & 46 \\
\hline & Male & 161 & 83,9 & 216 & 54 \\
\hline \multirow{4}{*}{ Age } & Aged 20-25 & 6 & 3,1 & 150 & 37,5 \\
\hline & Aged 26-30 & 72 & 37,5 & 178 & 85,3 \\
\hline & Aged 31-35 & 66 & 34,4 & 51 & 12,8 \\
\hline & Aged 36-40 & 48 & 25 & 21 & 5,3 \\
\hline \multirow{3}{*}{ Graduate School } & G. completing & 39 & 20,3 & 23 & 5,8 \\
\hline & Undergraduate & 110 & 57,3 & 341 & 85,3 \\
\hline & Graduate & 43 & 22,4 & 36 & 9 \\
\hline \multirow{2}{*}{ Field } & Class Teacher & 112 & 58,3 & 95 & 23,8 \\
\hline & Field teacher & 80 & 41,7 & 305 & 76,3 \\
\hline \multirow{7}{*}{ Professional Seniority } & $1-5$ years & 7 & 3,6 & 129 & 32,3 \\
\hline & $6-10$ years & 9 & 4,7 & 117 & 29,3 \\
\hline & $11-15$ years & 51 & 26,6 & 95 & 23,8 \\
\hline & $16-20$ years & 41 & 21,4 & 22 & 5,5 \\
\hline & $21-25$ years & 28 & 14,6 & 19 & 4,8 \\
\hline & $26-30$ years & 21 & 10,9 & 9 & 2,3 \\
\hline & 31 years or more & 35 & 18,2 & 9 & 2,3 \\
\hline \multirow{4}{*}{ Working Time } & $1-5$ year & 165 & 85,9 & 273 & 68,3 \\
\hline & 6-10 year & 8 & 4,2 & 71 & 17,8 \\
\hline & $11-15$ year & 9 & 4,7 & 41 & 10,3 \\
\hline & 16-20 year & 10 & 5,2 & 15 & 3,8 \\
\hline
\end{tabular}




\section{Findings and Discussion}

The difference between principals' and teachers' views about the level of implementation of strategic management in primary schools. Principles' and teachers' views on the level of implementation of strategic management in primary schools were given in Table 3; differentiation of these views according to groups was given in Table 4 .

As it seen in table 3, after analysing the principles' and teachers' views on the level of implementation of strategic management in primary schools, it was determined that strategic thinking is high as $(3,968 \pm 0,708)$; strategic guidance and forming strategy is high as $(4,110 \pm 0,624$ strategic implementation and evaluations is high as $(4,110 \pm$ 0,624). Eren [9] states that leadership has a vital role for both forming and determining strategies and implementing them. Wells [24] states that leaders should also be strategic thinkers. In the research, the fact that strategic implementation and evaluation rates are so high are the result of school principals' position in this implementation as the first degree responsible.

As it can be seen in table 3, after analysing teachers' views on the level of strategic implementation, it can be seen that strategic thinking rates are high as $(3,656 \pm 0,734)$; strategic analysis, guidance and forming strategy is high as $(3,879 \pm 0,688)$; strategic implementation and evaluation is high as $(3,891 \pm 0,755)$. Teacher disagree with the principles on the view that strategic implementation and evaluation is applied to a great extent. This difference may result from the fact that teachers are objective while evaluating the principals who are responsible for the process of strategic management. The results of the research overlap Altınkurt's [1] view which suggests that principals' leadership implementations related to strategy management are generally successful but need to be improved.

As it is seen in Table 3, after analysing all test subjects' views on the level of implementation of strategic management, it was determined that strategic thinking is high as $(3,812)$; strategic analysis, guidance and forming strategies is high as $(3,994)$; strategic implementation and evaluation is high as $(4,050)$.

Results of One-way variation analysis which was carried out to find out whether primary school principles' and teachers' views show a remarkable difference depending on the groups are shown in table 4. As it can be seen in table 4, a remarkable difference was found between the strategic thinking scores of participants $(\mathrm{F}=98,112 ; \mathrm{p}=0,000<0,05)$. As a result of Scheffe test which was conducted to specify the reasons for this difference, principals' strategic thinking scores were found higher than teachers'. The difference between participants' scores for strategic analysis, guidance and forming strategies was found remarkable $(\mathrm{F}=77,708$; $p=0,000<0,05)$. As a result of Scheffe test which was conducted to specify the reasons for this difference, principals' strategic analysis, guidance and forming strategy points was found higher than teachers'. The difference between participants' scores for strategic implementation and evaluation was found statistically remarkable $(\mathrm{F}=77,708$; $p=0,000<0,05)$. As a result of Scheffe test which was conducted to specify the reasons for this difference, principals' strategic implementation and evaluation scores were found higher than teachers'. The differentiation of school principals' and teachers' views depending on the variables such as gender, age, graduation school, field and Professional seniority.

Table 3. Arithmetic Mean Score of Principals, Teachers and All Participants'

\begin{tabular}{|c|c|c|c|c|c|c|}
\hline & \multicolumn{2}{|c|}{ Principal } & \multicolumn{3}{|c|}{ Teacher } & \multicolumn{2}{c|}{ Total } \\
\cline { 2 - 7 } & N & Ort. & N & Ort. & N & Ort \\
\hline Strategic thinking & 192 & 3,968 & 400 & 3,656 & 592 & 3,812 \\
\hline Strategic analysis, guidance and forming strategy & 192 & 4,110 & 400 & 3,879 & 592 & 3,994 \\
\hline Strategic implementation and evaluation & 192 & 4,210 & 400 & 3,891 & 592 & 4,050 \\
\hline
\end{tabular}

Table 4. One Way Variation Results Depending on School Principals' and Teachers' views

\begin{tabular}{|c|c|c|c|c|c|c|}
\hline & Group & $\mathbf{N}$ & Ort & Ss & $\mathbf{F}$ & $\mathbf{P}$ \\
\hline \multirow{2}{*}{ Strategic thinking } & Principal & 192 & 3,968 & 0,708 & \multirow{2}{*}{98,112} & \multirow{2}{*}{$0,000^{*}$} \\
\hline & Teacher & 400 & 3,656 & 0,734 & & \\
\hline \multirow{2}{*}{$\begin{array}{l}\text { Strategic analysis, guidance and } \\
\text { forming strategies }\end{array}$} & Principal & 192 & 4,110 & 0,624 & \multirow{2}{*}{77,708} & \multirow{2}{*}{$0,000^{*}$} \\
\hline & Teacher & 400 & 3,879 & 0,688 & & \\
\hline \multirow{2}{*}{$\begin{array}{l}\text { Strategic implementation and } \\
\text { evaluation }\end{array}$} & Principal & 192 & 4,210 & 0,644 & \multirow{2}{*}{82,602} & \multirow{2}{*}{$0,000^{*}$} \\
\hline & Teacher & 400 & 3,891 & 0,755 & & \\
\hline
\end{tabular}

${ }^{*} \mathrm{p}<0,05$ 
Table 5. T-Test Results of Principals' and Teachers' Views Depending on Gender

\begin{tabular}{|c|c|c|c|c|c|c|c|c|c|c|c|}
\hline & & \multicolumn{5}{|c|}{ School Principle } & \multicolumn{5}{|c|}{ Teacher } \\
\hline & G & $\mathbf{N}$ & Ort & Ss & $\mathbf{t}$ & $\mathbf{P}$ & $\mathbf{N}$ & Ort & Ss & $\mathbf{t}$ & $\mathbf{P}$ \\
\hline \multirow{2}{*}{ Strategic thinking } & $\mathrm{F}$ & 31 & 4,101 & 0,589 & \multirow{2}{*}{1,143} & \multirow{2}{*}{0,255} & 184 & 3,692 & 0,683 & \multirow{2}{*}{0,899} & \multirow{2}{*}{0,369} \\
\hline & $\mathrm{M}$ & 161 & 3,943 & 0,727 & & & 216 & 3,626 & 0,776 & & \\
\hline \multirow{2}{*}{$\begin{array}{l}\text { Strategic analysis, guidance and } \\
\text { forming strategies }\end{array}$} & $\mathrm{F}$ & 31 & 4,270 & 0,605 & \multirow{2}{*}{1,556} & \multirow{2}{*}{0,121} & 184 & 3,861 & 0,621 & \multirow[b]{2}{*}{$-0,471$} & \multirow[b]{2}{*}{0,638} \\
\hline & M & 161 & 4,080 & 0,625 & & & 216 & 3,894 & 0,742 & & \\
\hline \multirow{2}{*}{$\begin{array}{l}\text { Strategic implementation and } \\
\text { evaluation }\end{array}$} & $\mathrm{F}$ & 31 & 4,254 & 0,599 & \multirow{2}{*}{0,419} & \multirow{2}{*}{0,676} & 184 & 3,909 & 0,718 & \multirow{2}{*}{0,447} & \multirow{2}{*}{0,655} \\
\hline & $\mathrm{M}$ & 161 & 4,202 & 0,653 & & & 216 & 3,876 & 0,786 & & \\
\hline
\end{tabular}

$\mathrm{p}>0,05$

Table 6. Kruskal Wallis H-Test Results of the Views of School Principles and Teacher Based on Age

\begin{tabular}{|c|c|c|c|c|c|c|c|c|c|c|c|}
\hline & & \multicolumn{5}{|c|}{ Principal } & \multicolumn{5}{|c|}{ Teacher } \\
\hline & Group & $\mathbf{N}$ & Ort & Ss & KW & $\mathbf{P}$ & $\mathbf{N}$ & Ort & Ss & KW & $\mathbf{P}$ \\
\hline \multirow{4}{*}{$\begin{array}{l}\text { Strategic } \\
\text { thinking }\end{array}$} & Aged 20-25 & 6 & 4,011 & 0,540 & \multirow{4}{*}{11,108} & \multirow{4}{*}{$0,011^{*}$} & 150 & 3,591 & 0,738 & \multirow{4}{*}{1,099} & \multirow{4}{*}{0,349} \\
\hline & Aged 26-30 & 72 & 3,847 & 0,667 & & & 178 & 3,672 & 0,691 & & \\
\hline & Aged 31-35 & 66 & 3,892 & 0,844 & & & 51 & 3,802 & 0,724 & & \\
\hline & Aged $36-40$ & 48 & 4,249 & 0,484 & & & 21 & 3,632 & 1,038 & & \\
\hline \multirow{4}{*}{$\begin{array}{c}\text { Strategic } \\
\text { analysis, } \\
\text { guidance and } \\
\text { forming strategy }\end{array}$} & Aged 20-25 & 6 & 4,071 & 0,579 & \multirow{4}{*}{7,921} & \multirow{4}{*}{$0,048^{*}$} & 150 & 3,759 & 0,683 & \multirow{4}{*}{3,695} & \multirow{4}{*}{$0,012^{*}$} \\
\hline & Aged 26-30 & 72 & 3,998 & 0,635 & & & 178 & 3,928 & 0,646 & & \\
\hline & Aged 31-35 & 66 & 4,079 & 0,694 & & & 51 & 4,095 & 0,650 & & \\
\hline & Aged $36-40$ & 48 & 4,327 & 0,450 & & & 21 & 3,793 & 0,985 & & \\
\hline \multirow{4}{*}{$\begin{array}{c}\text { Strategic } \\
\text { implementation } \\
\text { and evaluation }\end{array}$} & aged $20-25$ & 6 & 4,056 & 0,491 & \multirow{4}{*}{6,895} & \multirow{4}{*}{0,075} & 150 & 3,797 & 0,760 & \multirow{4}{*}{1,770} & \multirow{4}{*}{0,152} \\
\hline & Aged 26-30 & 72 & 4,153 & 0,645 & & & 178 & 3,924 & 0,691 & & \\
\hline & Aged 31-35 & 66 & 4,128 & 0,751 & & & 51 & 4,061 & 0,760 & & \\
\hline & Aged $36-40$ & 48 & 4,428 & 0,428 & & & 21 & 3,868 & 1,119 & & \\
\hline
\end{tabular}

$* \mathrm{p}<0,05$

As it can be seen in Table 5, there isn't a remarkable difference between school principals' views on strategic thinking based on gender variable $(t=1,143 ; \mathrm{p}=0,255>0,05)$; in strategic analysis guidance and forming strategy aspect, there isn't a significant difference based on gender variable $(\mathrm{t}=1,556 ; \mathrm{p}=0,121>0,05)$. In strategic implementation and evaluation aspect, there isn't a significant difference based on gender variable $(t=0,419 ; p=0,676>0,05)$.

There isn't a remarkable difference between teachers' views on strategic thinking based on gender variable $(\mathrm{t}=0,899 ; \mathrm{p}=0,369>0,05)$; in strategic analysis, guidance and forming strategy aspect, there isn't a significant difference based on gender variable $(\mathrm{t}=-0,471 ; \mathrm{p}=0,638>0,05)$. In strategic implementation and evaluation aspect, there isn't a significant difference based on gender variable $(t=0,447$; $\mathrm{p}=0,655>0,05)$. Considering these findings, participants can state that their views on the level of implementation of strategic management in their schools don't differ in accordance with gender variable.

As it can be seen in Table-6, there is a remarkable difference between school principals' views on strategic thinking depending on age variable $(\mathrm{KW}=11,108$; $\mathrm{p}=0,011<0,05)$. To find out the reason for this difference Mann Whitney $U$ test was conducted. According to the results of this test, principles aged 26-30 have more strategic thinking scores than those who are aged 26-30 (Mann Whitney $U=1093,000 ; p=0,001<0,05)$. Principals aged $36-40$ have more strategic thinking scores than who are aged 31-35 (Mann Whitney $U=1221,000 ; p=0,037<0,05$ ). Considering the fact that principals' and teachers' way of appointment changed after 2000s it can be said that this difference may be the result of these changes.

There is a remarkable difference between school principals' views on strategic analysis, guidance and forming strategy depending on age variable $(\mathrm{KW}=7,921$; $p=0,048<0,05)$. To find out which group caused the difference Mann Whitney U test was conducted. According to this test, principals aged 36-40 have higher strategic analysis, guidance and forming strategy scores than those who are aged 26-30 (Mann Whitney $U=1210,500$; $\mathrm{p}=0,006<0,05)$. It can be said that the reason for this difference may be the result of the changes in principles' way of appointment.

There isn't a remarkable difference between principals' views on strategic implementation and evaluation aspect $(\mathrm{KW}=6,895 ; \mathrm{p}=0,075>0,05)$. There isn't a remarkable difference between teachers' views on strategic thinking aspect based on age variable $(F=1,099 ; p=0,349>0,05)$. 
There is a remarkable difference between teachers' strategic analysis, guidance and forming strategy. As a result of Scheffe test which was conducted to find out the reasons behind this difference, teachers aged 20-25 have higher scores for strategic analysis, guidance and forming strategy than those aged 31-35. This may be the result of the new appointment ways.

There isn't a remarkable difference on teachers' views on strategic implementation and evaluation based on age variable $(F=1,770 ; p=0,152>0,05)$.

As it is shown in Table 7, after one-way variable analysis, a remarkable difference wasn't found between principals' scores for "strategic thinking" based on the graduation school variable $(\mathrm{F}=0,073 ; \mathrm{p}=0,930>0,05)$. After one way variable analysis there wasn't a remarkable difference between principles' scores for "strategic analysis, guidance and forming strategy" based on the graduation school variable $(\mathrm{F}=0,563 ; \mathrm{p}=0,571>0,05)$. After one-way variable analysis there wasn't a remarkable difference between principals" scores for "strategic implementation and management" based on the graduation school variable $(\mathrm{F}=0,159 ; \mathrm{p}=0,853>0,05)$.

There isn't a remarkable difference between teachers' scores for "strategic thinking" aspect based on the school of graduate $(F=0,613 ; p=0,542>0,05)$. There isn't a remarkable difference between teachers' scores for "strategic analysis, guidance and forming strategy" aspect based on graduation school $(\mathrm{F}=0,215 ; \mathrm{p}=0,807>0,05)$. There isn't a remarkable difference between teachers' scores for "strategic implementation and management" aspect based on graduation school variable $(\mathrm{F}=0,049 ; \mathrm{p}=0,953>0,05)$.

According to these findings, it can be reported that graduation school variable does not have an impact on principals' and teachers' views on strategic management in primary schools.

As it is shown in Table 8, there wasn't a remarkable difference between principals' scores for "strategic thinking" based on the field variable $(t=-0,084 ; p=0,933>0,05)$. There wasn't a remarkable difference between principals' scores for "strategic analysis, guidance and forming strategy" based on the field variable $(t=-0,288 ; p=0,773>0,05)$. There wasn't a remarkable difference between principals' scores for "strategic implementation and evaluation" based on the field variable $(\mathrm{t}=-0,145 ; \mathrm{p}=0,885>0,05)$.

As it is shown in Table 8, there wasn't a remarkable difference between teachers' scores for "strategic thinking" based on the field variable $(t=0,163 ; p=0,870>0,05)$. There wasn't a remarkable difference between teachers' scores for "strategic analyses, guidance and forming strategy" based on the field variable $(\mathrm{t}=-0,630 ; \mathrm{p}=0,529>0,05)$. There wasn't a remarkable difference between teachers' scores for "strategic implementation and evaluation". Based on the field variable $(t=-0,447 ; p=0,655>0,05)$.

Table 7. Variation Analysis of Principals' and Teachers' Views Based on Graduation School

\begin{tabular}{|c|c|c|c|c|c|c|c|c|c|c|c|}
\hline & & \multicolumn{5}{|c|}{ Principal } & \multicolumn{5}{|c|}{ Teacher } \\
\hline & Group & $\mathbf{N}$ & Ort & Ss & $\mathbf{F}$ & $\mathbf{P}$ & $\mathbf{N}$ & Ort & Ss & $\mathbf{F}$ & $\mathbf{P}$ \\
\hline \multirow{3}{*}{$\begin{array}{l}\text { Strategic } \\
\text { thinking }\end{array}$} & $\begin{array}{l}\text { Grad. } \\
\text { Comp. }\end{array}$ & 39 & 3,930 & 0,705 & \multirow{3}{*}{0,073} & \multirow{3}{*}{0,930} & 23 & 3,732 & 0,950 & \multirow{3}{*}{0,613} & \multirow{3}{*}{0,542} \\
\hline & Und. Graduate & 110 & 3,976 & 0,756 & & & 341 & 3,664 & 0,722 & & \\
\hline & Graduate & 43 & 3,983 & 0,585 & & & 36 & 3,537 & 0,707 & & \\
\hline \multirow{2}{*}{$\begin{array}{c}\text { Strategy } \\
\text { analysis, } \\
\text { direction and } \\
\text { forming } \\
\text { strategy }\end{array}$} & Graduate & 110 & 4,150 & 0,604 & \multirow[t]{2}{*}{0,563} & \multirow[t]{2}{*}{0,571} & 341 & 3,888 & 0,676 & \multirow[t]{2}{*}{0,215} & \multirow[t]{2}{*}{0,807} \\
\hline & & 43 & 4,078 & 0,633 & & & 36 & 3,815 & 0,721 & & \\
\hline \multirow{2}{*}{$\begin{array}{l}\text { Strategic } \\
\text { implementation } \\
\text { and evaluation }\end{array}$} & Grad. Comp. & 39 & 4,231 & 0,655 & \multirow[b]{2}{*}{0,159} & \multirow[b]{2}{*}{0,853} & 23 & 3,932 & 0,948 & \multirow[b]{2}{*}{0,049} & \multirow[b]{2}{*}{0,953} \\
\hline & Und. Grad. & 110 & 4,188 & 0,685 & & & 341 & 3,887 & 0,743 & & \\
\hline
\end{tabular}

$\mathrm{p}>0,0$

Table 8. Results of T-Test of Principals' and Teachers' Views Based on Field Variable

\begin{tabular}{|c|c|c|c|c|c|c|c|c|c|c|c|}
\hline & \multirow[b]{2}{*}{ Group } & \multicolumn{5}{|c|}{ Principal } & \multicolumn{5}{|c|}{ Teacher } \\
\hline & & $\mathbf{N}$ & Ort & Ss & $\mathbf{T}$ & $\mathbf{P}$ & $\mathbf{N}$ & Ort & Ss & $\mathbf{t}$ & $\mathbf{P}$ \\
\hline \multirow{2}{*}{ Strategic thinking } & Class teacher & 112 & 3,965 & 0,682 & \multirow{2}{*}{$-0,084$} & \multirow{2}{*}{0,933} & 95 & 3,667 & 0,666 & \multirow{2}{*}{0,163} & \multirow{2}{*}{0,870} \\
\hline & Branch teacher. & 80 & 3,973 & 0,746 & & & 305 & 3,653 & 0,756 & & \\
\hline \multirow{2}{*}{$\begin{array}{l}\text { Strategic analysis, } \\
\text { guidance and } \\
\text { forming strategies }\end{array}$} & Class teacher & 112 & 4,099 & 0,579 & \multirow{2}{*}{$-0,288$} & \multirow{2}{*}{0,773} & 95 & 3,840 & 0,682 & \multirow{2}{*}{$-0,630$} & \multirow{2}{*}{0,529} \\
\hline & Branch teacher. & 80 & 4,126 & 0,686 & & & 305 & 3,891 & 0,691 & & \\
\hline \multirow{2}{*}{$\begin{array}{c}\text { Strategic } \\
\text { implementation and } \\
\text { evaluation }\end{array}$} & Class teacher & 112 & 4,204 & 0,626 & \multirow{2}{*}{$-0,145$} & \multirow{2}{*}{0,885} & 95 & 3,861 & 0,652 & \multirow{2}{*}{$-0,447$} & \multirow{2}{*}{0,655} \\
\hline & Branch teacher. & 80 & 4,218 & 0,672 & & & 305 & 3,901 & 0,785 & & \\
\hline
\end{tabular}

$\mathrm{p}>0,05$ 
According to these findings, it can be reported that the field variable does not have an impact on principals' and teachers' views on strategic management in primary schools.

As it is shown in Table 9, there wasn't a remarkable difference between principals' scores for "strategic thinking" based on the professional seniority variable $(\mathrm{KW}=7,156$; $\mathrm{p}=0,307>0,05)$. There wasn't a remarkable difference between principals' scores for "strategic analysis, guidance and forming strategy" based on the professional seniority variable $(\mathrm{KW}=5,588 ; \mathrm{p}=0,471>0,05)$. There wasn't a remarkable difference between principals' scores for "strategic implementation and evaluation" based on the professional seniority variable $(\mathrm{KW}=4,101 ; \mathrm{p}=0,663>0,05)$.

As it is shown in Table 9, there wasn't a remarkable difference between teachers' scores for "strategic thinking" based on the professional seniority variable $(\mathrm{KW}=6,255$; $\mathrm{p}=0,395>0,05)$. There wasn't a remarkable difference between teachers' scores for "strategic analyses, guidance and forming strategies" based on the professional seniority variable $(\mathrm{KW}=9,290 ; \mathrm{p}=0,158>0,05)$. There wasn't a remarkable difference between teachers' points for "strategic implementation and evaluation. Based on the professional seniority variable $(\mathrm{KW}=6,512 ; \mathrm{p}=0,368>0,05)$

\section{Results and Discussion}

In today's world, it is a necessity for schools and principals to embrace strategic management and implement it to enable schools to live and do their duties. More importantly, school principals should adopt strategic management in their schools. According to the results of this study, primary school principals think that "strategic thinking", "strategic analysis, guidance and strategy forming" is implemented in high levels and "strategic implementation and evaluation" is implemented in very high levels. This indicates that school principals give special attention to strategic management and internalise it. The fact that teachers think differently from the principles on two issues may be the sign that they evaluate the principles impartially. This view of teachers' shows parallelism with Altınkurt's [1] statement which ascertain that leadership practices of principles related to implement strategies are successful but need to be improved.

Table 9. Kruskal Test Results of Principles' and Teachers' Views Based on Professional Seniority Variable

\begin{tabular}{|c|c|c|c|c|c|c|c|c|c|c|c|}
\hline & & \multicolumn{5}{|c|}{ Principal } & \multicolumn{5}{|c|}{ Teacher } \\
\hline & Group & $\mathbf{N}$ & Ort & Ss & KW & $\mathbf{P}$ & $\mathbf{N}$ & Ort & Ss & KW & $\mathbf{P}$ \\
\hline \multirow{7}{*}{$\begin{array}{l}\text { Strategic } \\
\text { thinking }\end{array}$} & $1-5$ years & 7 & 3,881 & 0,736 & \multirow{7}{*}{7,156} & \multirow{7}{*}{0,307} & 129 & 3,617 & 0,737 & \multirow{7}{*}{6,255} & \multirow{7}{*}{0,395} \\
\hline & $6-10$ years & 9 & 4,133 & 0,599 & & & 117 & 3,623 & 0,726 & & \\
\hline & $11-15$ years & 51 & 3,854 & 0,736 & & & 95 & 3,708 & 0,674 & & \\
\hline & $16-20$ years & 41 & 3,883 & 0,747 & & & 22 & 3,608 & 0,834 & & \\
\hline & $21-25$ years & 28 & 3,894 & 0,795 & & & 19 & 3,926 & 0,775 & & \\
\hline & $26-30$ years & 21 & 4,051 & 0,752 & & & 9 & 3,430 & 1,180 & & \\
\hline & 31 years or more & 35 & 4,219 & 0,484 & & & 9 & 3,878 & 0,529 & & \\
\hline \multirow{7}{*}{$\begin{array}{c}\text { Strategic } \\
\text { analysis, } \\
\text { guidance and } \\
\text { forming strategy }\end{array}$} & $1-5$ years & 7 & 4,194 & 0,600 & \multirow{7}{*}{5,588} & \multirow{7}{*}{0,471} & 129 & 3,769 & 0,727 & \multirow{7}{*}{9,290} & \multirow{7}{*}{0,158} \\
\hline & $6-10$ years & 9 & 4,262 & 0,567 & & & 117 & 3,919 & 0,652 & & \\
\hline & $11-15$ years & 51 & 4,028 & 0,660 & & & 95 & 3,933 & 0,609 & & \\
\hline & $16-20$ years & 41 & 4,056 & 0,637 & & & 22 & 3,886 & 0,674 & & \\
\hline & $21-25$ years & 28 & 3,977 & 0,737 & & & 19 & 4,098 & 0,722 & & \\
\hline & $26-30$ years & 21 & 4,190 & 0,572 & & & 9 & 3,524 & 1,118 & & \\
\hline & 31 years or more & 35 & 4,298 & 0,480 & & & 9 & 4,238 & 0,624 & & \\
\hline \multirow{7}{*}{$\begin{array}{c}\text { Strategic } \\
\text { implementation } \\
\text { and evaluation }\end{array}$} & $1-5$ years & 7 & 4,175 & 0,748 & \multirow{7}{*}{4,101} & \multirow{7}{*}{0,663} & 129 & 3,817 & 0,783 & \multirow{7}{*}{6,512} & \multirow{7}{*}{0,368} \\
\hline & $6-10$ years & 9 & 4,272 & 0,434 & & & 117 & 3,869 & 0,718 & & \\
\hline & $11-15$ years & 51 & 4,142 & 0,705 & & & 95 & 3,963 & 0,673 & & \\
\hline & $16-20$ years & 41 & 4,192 & 0,651 & & & 22 & 3,864 & 0,819 & & \\
\hline & $21-25$ years & 28 & 4,083 & 0,756 & & & 19 & 4,135 & 0,857 & & \\
\hline & $26-30$ years & 21 & 4,233 & 0,659 & & & 9 & 3,728 & 1,235 & & \\
\hline & 31 years or more & 35 & 4,410 & 0,428 & & & 9 & 4,198 & 0,664 & & \\
\hline
\end{tabular}

$\mathrm{p}>0,05$ 
The fact that principals have more scores for three levels compared to teachers' can be interpreted as that principles try to implement strategic management in a better way by internalising it. According to the views of participants of the research; it can be concluded that strategic management is implemented in primary schools with "strategic thinking", "strategic analysis", "guidance and strategic implementation and evaluation" aspects to a great extent.

According to the results of the research, there is no individual difference between principals' and teachers' views on the level of implementation of strategic management in primary schools with the exception of age variable. This is what Ülker [21] says about the issue. According to principals and teachers: as the age increases so do the scores for the level of implementation of strategic management in primary schools. This situation may result from the increasing qualities of teachers because of the exams and eliminations before teacher appointments after 2000 s

At the end of this study, following suggestions were made;

- Because of the fact that teachers in this study have the opinion that the level of implementation of strategic management is not high; comprehensibility and share ability of the concept "strategic thinking" should be increased with the help of in-service training programs.

- The literature view has shown that the number of studies on strategic management is little, so Ministry of Education should support qualitative and quantitative studies by reinforcing strategic management implementations in schools through Directorate of National education.

\section{REFERENCES}

[1] Altınkurt, Y. (2007). Eğitim örgütlerinde stratejik liderlik ve okul müdürlerinin stratejik liderlik uygulamaları. Unpublished PhD Thesis, Eskişehir: Anadolu University Institute of Educational Sciences.

[2] Aktan, C. C. (1999). 2000'li yıllarda yeni yönetim teknikleri stratejik yönetim. İstanbul: Simge Ofis Matbaacılık.

[3] Arlı, M., Nazik, M. H. (2001). Bilimsel araştırmaya giriş. Ankara: Gazi Kitapevi.

[4] Bush, T. and Coleman, M. (2008). Leadership and strategic management in education. California: Sage Publications Inc.

[5] Çelik, V. (1995). Eğitim yöneticisinin vizyonu ve misyonu. Eğitim Yönetimi. Say11, 47-52.

[6] Çetinkanat A, C. (1988). Örgütsel iklim ve iş doyumu. Unpublished $\mathrm{PhD}$ Thesis. Hacettepe University Institute of Social Sciences.
[7] Drucker, P., F. (1995). Gelecek için yönetim, (translated: Fikret Üçcan). Ankara: Türkiye İş Bankası Cultural Publications, No: 327.

[8] Erdem, A. (2006). Stratejik yönetim ve kamu örgütlerinde uygulanabilirliği. Unpublished Master's Thesis, Mersin University Institute of Social Sciences, Mersin.

[9] Eren, E. (2000). Stratejik yönetim ve işletme politikası. İstanbul: Beta Basım Yayım Dağıtım A. Ş.

[10] Erdoğan, İ. (2004). Eğitimde Değişim Yönetimi. (2. Baskı). Ankara: PegemA publications.

[11] Ertan, Y. (2010), Stratejik yönetimin kamu yönetimi alanında uygulanması ve sorunlar1. Unpublished Master's Thesis, Selçuk University Institute of Social Sciences. Department of Public Administration, Konya.

[12] Genç, N. (1994). Zirveye götüren yol yönetim. İstanbul: Timaş publications.

[13] Güçlü, N. (2003). Stratejik yönetim. Gazi Faculty of Education Journal, 2 (23), 61-85.

[14] Karasar, N. (2005). Bilimsel araştırma yöntemi: kavramlar, ilkeler ve teknikler. Ankara: Nobel publications.

[15] Kırım, A. (2002). Farklı Olan Kazanır: Farklılığınızı Ölçebildiğiniz An. İstanbul: Sistem publications.

[16] Koç, U ve Taşçı, D. (2006). Yarının organizasyonları için bugünden ipuçları. Journal of İstanbul Kültür University, 4, 145-152.

[17] Machiavelli, (1996). Hükümdar. (translated. Y. Türk). İstanbul: Düşünen Adam Publication.

[18] MEB. (2010). Eğitimde stratejik planlama - okul/kurumlar için. Ankara: Strateji Geliştirme Başkanlığı.

[19] Quinn, J. B, Henry M. and Robert M. J. (1996). The strategy process. New Jersey: Prentice Hall.

[20] Terzi, Ç. (2005). Uyum sürecinde Türkiye eğitim politikalarının Avrupa birliği eğitim politikaları doğrultusunda değerlendirilmesi. Unpublished PhD Thesis, Eskişehir: Anadolu University Institute of Educational Sciences.

[21] Ülker, M. (2009). Okul yöneticilerinin stratejik liderlik özelliklerine ilişkin öğretmen algıları. Unpublished Master's Thesis, Kocaeli University Institute of Social Sciences.

[22] Yenipınar, Ş. (2014), Stratejik ilköğretim okullarında uygulanma düzeyi. Unpublished $\mathrm{PhD}$ Thesis, Bolu. Abant İzzet Baysal University Institute of Educational Sciences. Educational Administration and Supervision Department

[23] Yıldırım, A. Şimşek, H. (2008). Sosyal bilimlerde nitel araştırma yöntemleri. Ankara: 7. publication.

[24] Wells, D. L., Strategic management for senior leaders: a handbook for implementation. http://unpan1.un.org/intradoc/groups/public/documents/ASP A/UNPAN002503.pdf 23.04.2012 accessed on.

\footnotetext{
i This study was taken from doctoral study at the Abant İzzet Baysal University Educational Science Institute by Şenyurt Yenipınar.
} 